\title{
Evaluation Drip Irrigation Method for Hot Peppers Production Using Roof-top Rain Water in Home Garden Irrigation at Water Scarce Area of Fadis, Estern Oromia Region
}

\author{
Lalisa Ofgea* Jemal Nur \\ Oromia Agricultural Research Institute, Fadis Agricultural Research Centre, P.o.Box, 904, Harar, Ethiopia
}

\begin{abstract}
Existing fresh water resources are subjected to an ever-increasing pressure due to extensive agricultural water demand for irrigated lands. A long-term perspective in shortage of fresh water resources, especially in arid and semi-arid area, highlights an urgent solution for innovative irrigation technologies and agricultural water management strategies. The experiment was conducted at Fadis agricultural research center farm in Boko station. The aim of the study was to evaluate performance of hot pepper varieties under drip irrigation system using water harvested from roof top on growth and yield parameters. The experiment was arranged in RCBD, replicated three times. Three hot pepper varieties namely: mareko fana, malka awaze and local check were used as experimental crop. The result on yield and plant height showed that there was significance difference $(\mathrm{P}<0.05)$ between mareko fana and malka awaze with local check hot pepper varieties when irrigated with equal water application. In case of hot pepper number of main branch, there was significant difference $(p<0.05)$ between each hot pepper varieties under drip irrigation system. Number of fruit per plant, had significance difference between local check and malka awaze. The yield obtained for both mareko fana and melka awaze hot pepper varieties were satisfactory, therefore both varieties were recommended for further use under drip irrigation system in the study area and other similar agro ecologies.
\end{abstract}

Keywords: Crop water requirement; drip irrigation; hot pepper performance.

DOI: $10.7176 / \mathrm{JRDM} / 59-02$

Publication date:September $30^{\text {th }} 2019$

\section{Introduction}

Water required by crops is supplied by nature in the form of precipitation, but when it becomes scarce or its distribution does not coincide with demand peaks, it is then necessary to supply it artificially, by irrigation. A major reason for the low and erratic rate of growth in agricultural production is the highly uncertain and unpredictable rainfall, combined with low soil fertility (FAO, 2003). Even in years of 'average' rainfall, a shortfall during critical periods of crop growth often leads to widespread crop failure. Therefore, water storage is absolutely crucial for stabilizing and increasing crop yields (FAO, 2003). Several irrigation methods are available, and the selection of one depends on factors such as water availability, crop type, soil characteristics, land topography, and associated cost. In the near future, irrigated agriculture will need to produce two-thirds of the increase in food products required by a larger population (English et al., 2002).

Research and development of water saving agriculture is a challenging task today to make agriculture and industries sustainable in term of water consumption. Although satisfying crop water requirement can maximize production from the land unit, it does not necessarily maximize the return per unit volume of water (Oweis et al, 2000). Advanced irrigation methods and water management practices coupled with proper irrigation scheduling can help achieve high crop yields with minimum water applications.

Pepper is extensively used as spice and diet in Ethiopia. There are two important types: hot pepper and sweet pepper. Irrigation is essential in arid and semi-arid regions to provide adequate moisture for production of peppers. Today, many hectares of peppers are grown with irrigation in the semi-arid regions of the world. The total world production of this crop has been estimated to be 14 to 15 million tons a year (Weiss, 2002). Della Costa and Gianquinto (2002) reported that continuous water stress significantly reduced total fresh weight of pepper fruits. Moreover, Antony and Singand (2004) found that the total pepper yield was less at lower levels of irrigation.

Ideally, in irrigation schemes, crops do not suffer from water shortages as water is applied before the crops are under stress. However, it may not be possible to apply the irrigation water exactly when it would be best. The farmers may be badly organized and lose too much water at the upstream end of the scheme, thus causing problems downstream. The scheme management may decide to spread the available water over a large area, thus allowing more farmers to irrigate, although less than the optimal amount.

About $90 \%$ of the irrigated land of the world is irrigated using relatively inefficient surface irrigation methods (FAO, 2002). Similarly in Eastern Ethiopia traditional surface irrigation methods (basin, border and furrow) are widely used to irrigate crops, though there is acute water shortage. In this region, traditional surface irrigation methods has long been practiced at different farm levels, however, there is no efficient and well 
managed irrigation water practice. There are very few or no information regarding appropriate irrigation water management practices for the rapidly expanding small scale irrigation farms in the country. Now a day the modern, high-tech and efficient micro irrigation methods (drip, bubbler, sprinkler etc.) are advocated worldwide. Efficient irrigation system or method, such as drip irrigation supply water directly to the plants effective root zone and thereby minimize water loss through evaporation, deep percolation and runoff as compared to surface irrigation. To overcome such problem in areas where water is scarce, the use of modern irrigation techniques will greatly demanding. Therefore; the aim of this study was to evaluate the performance of hot pepper varieties under drip irrigation system using rain water harvested from roof top.

\section{Materials and Methods \\ Experimental site}

The experiment was conducted at Boko sub-station of Fadis Agricultural Research Center in Fadis woreda. The station is situated at $09^{0} 07^{\prime} 51.6^{\prime \prime}$ North latitude, $042^{\circ} 04^{\prime} 24.3$ " East longitude and elevation of $1615 \mathrm{~m}$ a.s.1. The study area is found at $554 \mathrm{~km}$ distance from the capital city of Ethiopia (Finfine) and $24 \mathrm{~km}$ from the capital city of Eastern Hararghe zone (Harar). Climatologically, the area received average annual rain fall of $827.59 \mathrm{~mm}$ and; mean minimum and maximum temperature of 9.28 and $28.4{ }^{\circ} \mathrm{C}$ respectively.

\section{Experimental design}

Three treatments (Mereko Fana, malka awaze and local check hot pepper varieties) were laid out under drip irrigation in randomized complete Block design. The treatments were replicated three times. The sizes of each experimental plot were $2.4 \mathrm{~m}$ x $2.95 \mathrm{~m}$. Distance between plots was $1 \mathrm{~m}$ and distance between block was $1.5 \mathrm{~m}$. The inter-row spacing of hot pepper was $60 \mathrm{~cm}$ which is equal with drip lateral line and plant spacing of $30 \mathrm{~cm}$ was used. Transplanting was under taken when the seedling height reached $12-15 \mathrm{~cm}$. Transplanting was done late in the afternoon to reduce the risk of poor establishment and $200 \mathrm{~kg} \mathrm{ha}^{-1}$ of $\mathrm{P}_{2} \mathrm{O}_{5}$ and $100 \mathrm{~kg} \mathrm{ha}^{-1}$ of N fertilizer were applied through fertigation at initial and mid stage.

\section{Soil analysis}

Soil samples from the experimental plots were taken to analyze bulk density, texture, moisture content at filed capacity and permanent wilting point from the field at three points along the diagonal of the experimental plot at two depth 0-20 cm, 20-40 $\mathrm{cm}$ and 40-60 $\mathrm{cm}$ and average value was described.

\section{Infiltration rate of soil}

To determine infiltration rate double ring inflitrometre was used. The measurement was done at two site randomly selected within experimental plot (FAO, 1998).

\section{Crop water requirement}

Irrigation water was applied based on crop water requirement estimated from the Fadis metrological station. Gross irrigation requirement, net irrigation requirement and all irrigation schedules was calculated with the help of FAO cropwat 8.0 model. Crop evapotranspiration (ETc) was determined for each growing stages as:

$$
\mathrm{ETc}=\mathrm{Kc}^{*} \mathrm{ET}_{\mathrm{o}}
$$

Where:

$\mathrm{ETc}=$ Crop water requirement in mm per unit of time: $\mathrm{Kc}=$ Crop factor (crop coefficient)

$\mathrm{ET}_{\mathrm{o}}=$ Reference crop evapotranspiration in mm per unit time

Table 1: Climatic data used in determination of crop water requirement from Fadis meteorological station.

\begin{tabular}{|c|c|c|c|c|c|c|}
\hline \multicolumn{7}{|c|}{ 2014/2015 - Growing season } \\
\hline Month & $\begin{array}{c}\mathrm{Min} / \text { tem. } \\
\left({ }^{0} \mathrm{C}\right)\end{array}$ & $\begin{array}{l}\text { Max.tem. } \\
\left({ }^{0} \mathrm{C}\right)\end{array}$ & $\begin{array}{l}\text { Humidity } \\
(\%)\end{array}$ & $\begin{array}{l}\text { Wind speed } \\
\left(\mathrm{km} \mathrm{hr}^{-1}\right)\end{array}$ & $\begin{array}{l}\text { Sun shine } \\
\text { hour }\end{array}$ & $\begin{array}{l}\text { Precipitation } \\
(\mathrm{mm})\end{array}$ \\
\hline September & 9.7 & 26.8 & 60.3 & 1.8 & 9.04 & 28 \\
\hline October & 8.3 & 28.2 & 34.2 & 2.16 & 8.58 & 10.6 \\
\hline November & 8.0 & 28 & 37 & 2.54 & 7.74 & 0.00 \\
\hline December & 6.5 & 27.8 & 27.8 & 4.29 & 7.32 & 0.00 \\
\hline January & 6.3 & 28.5 & 28.9 & 6.83 & 7.28 & 5.4 \\
\hline \multicolumn{7}{|c|}{ 2015/2016 - growing season } \\
\hline November & 9.6 & 30.62 & 32.8 & 3.09 & 7.74 & 28 \\
\hline December & 11.06 & 29.32 & 46.04 & 2.51 & 7.32 & 0.00 \\
\hline January & 10.92 & 27.98 & 56.82 & 2.01 & 7.28 & 8.40 \\
\hline February & 10.74 & 27.66 & 56.04 & 2.37 & 6.44 & 0.00 \\
\hline March & 10.70 & 28.58 & 60.3 & 2.37 & 6.70 & 3.62 \\
\hline
\end{tabular}




\section{Determination of water application time}

The duration of irrigation water application for each treatment was computed as follows:

$$
\text { Duraation }(\mathrm{hr})=\frac{\text { Water requirment }(\mathrm{mm})}{\text { Application rate } \mathrm{mm} \mathrm{hr}^{-1}}
$$

Wetted diameter was measured by exposing a vertical plane passing through the point of application by taking three samples from all points of application. Wetted area of each emitter was calculated as:

$$
A=\frac{\pi D^{2}}{4}
$$

where;

$A=$ Wetted area covered by each emitter $\left(\mathrm{m}^{2}\right)$

$\mathrm{D}=$ Average wetted diameter covered by each emitter $(\mathrm{m})$

\section{Irrigation system design, field layout and water application method}

Irrigation water was obtained from rooftop rain water harvested during rainy season for the experiment which was then stored in concrete lined reservoir/tank near the experimental plots. Three concrete reservoirs were constructed at appropriate place around the houses for collecting rainwater. Each reservoir was designed to have a storage capacity of $25 \mathrm{~m}^{3}$, and yielding a total of $75 \mathrm{~m}^{3}$.

The required amount of irrigation water was applied by drip irrigation system from temporary water storing tank. The water in ground reservoir was fetched into elevated temporary water storing tank. This water was distribution on above ground thank placed at a height of $1.30 \mathrm{~m}$ at appropriate pressure head to supply required amount of water for each plot. The main line receives water directly from the water storing tank and distributed each laterals.

Drip system consisted of water storing tank, main lines; sub main lines, lateral lines, emitters and regular filter. The sub main line was connected to the mainline. The drip lateral lines in each plot received equal amount of irrigation water from the sub main line. The spacing between each emitter was $30 \mathrm{~cm}$ and between lateral was $60 \mathrm{~cm}$ which match with the intra- and inter-row spacing of the test crop.

\section{Statistical analysis}

All agronomic and yield parameters were subjected to analysis of variance appropriate for randomized complete block design (RCBD). The data were analyzed using Genstat $15^{\text {th }}$ edition statistical software. The mean separation was made using fisher protected list significant difference (LSD) method.

\section{Results and Discussion}

Soil physical properties of experimental site

The soil physical properties of experimental site was presented in Table 2. The analysis of particle size distribution indicated that the soil texture at depths of 0-40 cm was sandy loam, but at lower depth $(40-60 \mathrm{~cm})$ it was found sandy clay loam. The average soil bulk density $\left(0-60 \mathrm{~cm}\right.$ soil depth) was $1.51 \mathrm{~g} \mathrm{~cm}^{-3}$. The top soil had relatively lower available water content when compared to the subsoil (Table 2). Average value of soil moisture content at field capacity and permanent wilting point was observed as $23.4 \%$ and $14.3 \%$ in volume base respectively.

Table 2: Soil physical properties of experimental area

\begin{tabular}{llllllll}
\hline \multirow{2}{*}{$\begin{array}{l}\text { depth } \\
(\mathrm{cm})\end{array}$} & \multicolumn{2}{l}{ Particle size distribution (\%) } & Soil textural class & PWP (\%) & FC (\%) & Bd \\
& Sand & Silt & Clay & & & & $\left(\mathrm{g} / \mathrm{cm}^{3}\right)$ \\
\hline $0-20$ & 69 & 11 & 20 & Sandy loam & 13.8 & 22.4 & 1.51 \\
$20-40$ & 68 & 12 & 20 & Sandy loam & 13.8 & 22.5 & 1.51 \\
$40-60$ & 66 & 12 & 22 & Sandy clay loam & 14.9 & 24.0 & 1.51 \\
\hline Average & 67.66 & 11.67 & 20.66 & Sandy clay loam & 14.3 & 23.1 & 1.51 \\
\hline
\end{tabular}

\section{Infiltration rate of soil}

Infiltration rate was measured using double ring infiltrometer. The measurement was done at randomly selected site within experimental area. The field level infiltration test indicated that basic infiltration rate of the experimental area was $21 \mathrm{~mm} \mathrm{hr}^{-1}$ (Table 3). This result agrees with basic infiltration rate range of USDA (16 $50 \mathrm{~mm} \mathrm{hr}^{-1}$ ) for sandy clay loam (NRCS, 1995).

\section{Agronomic and yield related parameters of hot pepper varieties}

Analysis of variance showed that there was significance difference $(\mathrm{P}<0.05)$ in yield and plant height obtained 
between mareko fana and local check as well as between malka awaze and local check irrigated with equal amount of irrigation water under drip irrigation system. But there was no significance difference in case of yield and plant height produced by using improved varieties in two consecutive years. Fresh fruit yield of 15.58 and 13.76 ton $\mathrm{ha}^{-1}$ was produce by mareko fana and malka awaze respectively (Table 4). This might be due to improved varieties selected were high yielder and vigorous in fruit size than local variety. Moreover from field observation more watering local variety resulted in promoting vegetative growth than yield when compared to improved varieties.

Number of fruit per plant, main branches and height of hot pepper were also evaluated. In case of number of main branch, there was significant different $(\mathrm{p}<0.05)$ between each hot pepper varieties. Statistical output indicated that mean number of fruit per plant, had no significant difference between improved varieties; but local check and malka awaze had significance different at $\mathrm{p}<0.05$ (Table 4). The result indicated that regular watering of improved variety may change crop phonology at each growth stage, but local variety might need timing for physiological growth as observed. In addition to this, this result revealed that crop physiological growth may not depend on water supply rather than crop variety.

Table 4: Agronomic and yield related parameters of hot pepper varieties (mean of two consecutive cropping season, 2015 and 2016 years)

\begin{tabular}{llllllc}
\hline Treatment & $\begin{array}{c}\text { Yield (ton } \\
\left.\text { ha }^{-1}\right)\end{array}$ & $\begin{array}{c}\text { Fruit per } \\
\text { plant }\end{array}$ & $\begin{array}{c}\text { No main } \\
\text { branch }\end{array}$ & $\begin{array}{c}\text { Plant height } \\
(\mathrm{cm})\end{array}$ & $\begin{array}{c}\text { ETc } \\
(\mathrm{mm})\end{array}$ & $\begin{array}{c}\text { Water used } \\
\left(\mathrm{m}^{3} \mathrm{ha}^{-1}\right)\end{array}$ \\
\hline Marakofana & $15.6^{\mathrm{a}}$ & $79.0^{\mathrm{ab}}$ & $12.2^{\mathrm{a}}$ & $42.7^{\mathrm{a}}$ & 445.4 & 2254 \\
Local check & $8.2^{\mathrm{b}}$ & $73.5^{\mathrm{b}}$ & $7.5^{\mathrm{c}}$ & $38.7^{\mathrm{b}}$ & 445.4 & 2254 \\
Melka Awaze & $13.8^{\mathrm{a}}$ & $85.3^{\mathrm{a}}$ & $10.2^{\mathrm{b}}$ & $44.0^{\mathrm{a}}$ & 445.4 & 2254 \\
\hline LSD & $3.9^{*}$ & 8.7 & $1.4^{*}$ & 3.7 & & \\
\hline
\end{tabular}

From first season, the yield produced in 2015 cropping season indicated that there was significant difference $(\mathrm{p}<0.05)$ between mareko fana and local check hot pepper varieties, but no significant difference among mareko fana and malka awaze, and also between malka awaze and local check (Table 5). Similarly mean yield recorded between mareko fana and local check as well as malka awaze and local check in second year (2016) was significantly different at $(\mathrm{p}<0.05)$, but mareko fana and malka awaze had no significant difference (Table 5).

Table 5: Yield performance of hot pepper varieties evaluated under drip irrigation system for 2015 and 2016 copping season

\begin{tabular}{|c|c|c|c|c|c|c|}
\hline \multirow{3}{*}{ Treatment } & \multicolumn{6}{|c|}{ Yield performance of hot pepper varieties in } \\
\hline & \multicolumn{3}{|c|}{ First season (2015) } & \multicolumn{3}{|c|}{ Second season (2016) } \\
\hline & Yield (ton ha-1) & $\begin{array}{c}\text { Water used } \\
\left(\mathrm{m}^{3} \mathrm{ha}^{-1}\right)\end{array}$ & ETc $(\mathrm{mm})$ & $\begin{array}{c}\text { Yield } \\
\left(\text { ton } \mathrm{ha}^{-1}\right)\end{array}$ & $\begin{array}{l}\text { ETc } \\
(\mathrm{mm})\end{array}$ & $\begin{array}{c}\text { Water used } \\
\left(\mathrm{m}^{3} \mathrm{ha}\right)\end{array}$ \\
\hline Marakofana & $15.44^{\mathrm{a}}$ & 2230.64 & 433.80 & $15.72^{\mathrm{a}}$ & 456.93 & 2276.49 \\
\hline Local check & $5.30^{\mathrm{b}}$ & 2230.64 & 433.80 & $11.18^{\mathrm{b}}$ & 456.93 & 2276.49 \\
\hline Melka Awaze & $13.25^{\mathrm{ab}}$ & 2230.64 & 433.80 & $14.27^{\mathrm{a}}$ & 456.93 & 2276.49 \\
\hline LSD & $8.61 *$ & & & $1.66^{*}$ & & \\
\hline
\end{tabular}

\section{Conclusion and Recommendation}

Most Ethiopian farmers depend on rain-fed agriculture. However, rainfall is very erratic, and drought occurs frequently in most part of eastern Ethiopia, especially in East Hararghe zone. Due to this problem, a huge activity of rainwater harvesting and also ground water utilization for irrigation sustaining vegetable production at household levels have been going on. Thus, efficient use of irrigation water using appropriate irrigation system and management is an important consideration in the drought prone areas of the region for improving water productivity and crop production. Therefore, the study was conducted to evaluate the performance of three hot pepper varieties under drip irrigation system using roof top rain water harvesting at Boko sub-station of Fadis Agricultural Research Center.

The yield difference was observed between mareko fana and local check, as well as malka awaze and local check varieties when equal amount of irrigation water was applied by drip irrigation system. The highest fresh fruit yield of 15.58 ton/ha was obtained from mareko fana followed by malka awaze and local check (13.76 and 8.24 ton/ha) hot pepper varieties respectively. Whereas, the yield recorded by mareko fana and mmalka awaze had no significant difference among them for two consecutive growing period (2015 and 2016). Generally, both pepper varieties mareko fana and malka awaze performed well under drip irrigation system. Therefore both pepper varieties were recommended for farmers' as future uses under drip irrigation system in and around study area or in the similar agro ecologies. 


\section{Acknowledgement}

We wish to thank Oromia Agricultural Research Institute for funding the study. We would also like to thank Mr. Habte Birhanu who helps us in the analysis of collected data. Lastly but not list we would like to thank researchers and technical support of soil and water engineering team Fadis agricultural research center.

\section{References}

Antony, E. and Singandhupe, R.B. (2004) Impact of drip and surface irrigation on growth, yield and WUE of capsicum (Capsicum annuum L.), Agric. Water Manag., 65(2): 121-132.

Della Costa, L. and Gianquinto, G. (2002) Water stress and water-table depth influence yield, water use efficiency and nitrogen recovery in bell pepper: lysimeter studies, Aust. J. Agric. Res., 53: 201-210.

English, M.J.; Salomon, K.H.; Hoffman, G.J. (2002). A paradigm shift in irrigation management, J. Irrigation and Drainage Engineering, 128(5), 267-277.

FAO, 1998. Institution and technical operations in the development and management of Small Scale Irrigation. Proceedings of the third session of the Multilateral Cooperation Workshops for Sustainable Agriculture, Forestry and Fisheries development, Tokyo Japan, February 1995, FAO water paper, No. 17. Rome. pp 21 38.

Food and Agriculture Organization of the United Nations. 2002. Crops and drops: Making the best use of water for agriculture Natural Resources Environ. Dept., FAO, Rome

FAO (Food and Agriculture Organization of the United Nations). 2003. A perspective on water control in southern Africa: Support to regional investment initiatives. Land and Water Discussion Paper 1. FAO, Rome, Italy.

Oweis, T. Zhang, H and Pala, M. (2000) Water uses efficiency of rainfed and irrigated bread wheat in a Mediterranean environment. Agronomy Journal 92: 231-238

USDA NRCS (U.S. Department of Agriculture, Natural Resources Conservation Service). 1995. Soil Survey Geographic (SSURGO) Data Base: Data Use and Information. Miscellaneous Publication Number 1527. Washington, DC

Weiss, E.A. (2002) World Production and Trade, CABI Publishing, CAB International, Wallingford, UK. 